\title{
Transformasi Musik Tradisional Rinding Gumbeng Perspektif Postkolonial
}

\author{
Vivi Ervina Dewi
}

Universitas Negeri Surabaya

Email: vividewi@unesa.ac.id

\begin{abstract}
Rinding gumbeng is a traditional musical instrument that lives and develops in the Gunungkidul area. However, along with the development of modernization, the traditional music of Rinding Gumbeng is slowly being questioned. This can be seen from the current reality with the large number of Ngawen people, especially those in Gunungkidul who are more interested in enjoying or learning the art of western music such as popular music and modern music. Changes in people's musical tastes can occur due to changes in the environment of the Gunungkidul community, the many elements of material culture that enter the Gunungkidul community, and the way of life and life outlook of the Gunungkidul people are changing. Today, people are faced with a variety of difficult choices because of the rise of cultural industry products that are presented. The influence of music in human life, especially traditional music in the archipelago began to be ruled out. Pop music or the art of western music at this time began to become gods and goddesses in the midst of society. Society thinks that pop music or western art music is music that can have a great influence on human life. Western art music is more able to be enjoyed by the public than traditional music in the archipelago. As a result, traditional music in the archipelago such as traditional music Rinding Gumbeng slowly began to be abandoned and ignored by the community. The turmoil that arose in the Gunungkidul community was an effect of the post-colonial era. People do not realize that they are being colonized by western nations through various means such as the arrival or entry of western music in Indonesia.
\end{abstract}

Keywords: transformation, Rumbar Gumbeng, postcolonial.

Abstrak: Rinding gumbeng merupakan salah satu alat musik tradisional yang hidup dan berkembang di daerah Gunungkidul. Akan tetapi seiring dengan perkembangan modernisasi zaman, musik tradisional Rinding Gumbeng ini perlahan mulai dipertanyakan eksistensinya. Hal tersebut dapat dilihat dari realita yang ada pada saat ini dengan banyaknya masyarakat Ngawen terutama masyarakat di Gunungkidul yang lebih tertarik untuk menikmati ataupun mempelajari seni musik barat seperti musik popular dan musik-musik modern. Perubahan-perubahan selera musik masyarakat tersebut dapat terjadi oleh adanya perubahan lingkungan masyarakat Gunungkidul, banyaknya elemen kebudayaan material yang masuk dalam lingkungan masyarakat Gunungkidul, dan cara hidup serta pandangan hidup masyarakat Gunungkidul yang berubah. Dewasa ini, masyarakat dihadapkan dengan berbagai pilihan yang sulit karena maraknya produk-produk industri kebudayaan yang disajikan. Pengaruh musik dalam kehidupan manusia khususnya musik tradisional yang ada di Nusantara mulai dikesampingkan. Musik pop atau seni musik barat pada saat ini mulai menjadi dewa-dewi di tengah masyarakat. Masyarakat beranggapan bahwa musik pop ataupun musik seni barat merupakan musik yang dapat memberikan pengaruh yang besar terhadap kehidupan manusia. Musik seni barat lebih bisa untuk dinikmati oleh masyarakat daripada musik-musik tradisional yang ada di Nusantara. Akibatnya, musik tradisional yang ada di Nusantara seperti musik tradisional Rinding Gumbeng perlahan mulai ditinggalkan dan diabaikan oleh masyarakat. Gejolak-gejolak yang timbul pada masyarakat Gunungkidul tersebut merupakan efek dari post-kolonial. Masyarakat tidak menyadari bahwa dirinya sedang dijajah oleh bangsa barat melalui berbagai cara seperti datangnya atau masuknya kesenian musik barat di Indonesia.

Kata Kunci: transformasi, Rinding Gumbeng, postkolonial.

\section{PENDAHULUAN}

Kekayaan seni budaya Indonesia merupakan warisan yang sangat berharga bagi penduduk dan masyarakatnya. Awal kemajuan suatu bangsa, dimulai dengan pelestarian tradisi seni dan budaya yang pada akhirnya akan memperkuat jati diri suatu bangsa. Indonesia, merupakan salah satu negara kepulauan terbesar di dunia. Hal inilah yang menyebabkan
Indonesia kaya akan sumber daya alam dan seni budaya. Setiap daerah di Indonesia memiliki kebudayaan dan kesenian tersendiri yang berbeda satu sama lain. Kebudayaan dan kesenian yang berbeda antara satu daerah dengan daerah lain yang kemudian menjadi ciri khas dari masing-masing daerah di Indonesia. Aneka ragam kebudayaan dan kesenian yang berbeda-beda antara daerah satu dengan daerah 
lain menjadikan masyarakat Indonesia mempunyai sikap toleransi yang tinggi, saling menghargai, dan saling menghormati satu sama lain.

Kesenian tradisional yang berkembang secara turun-temurun mempunyai unsur-unsur kepercayaan dan interpretasi tradisi masyarakat. Hal tersebut umumnya menjadi ciri khas dari sebuah kesenian tradisional di Indonesia. Kesenian tradisional merupakan warisan nenek moyang yang hingga saat ini masih hidup dan dijalankan oleh masyarakat. Seperti yang diungkapkan oleh Koentjaraningrat (2000: 203204), kesenian merupakan salah satu unsur kebudayaan universal, merupakan unsur yang paling utama dalam kebudayaan Indonesia. Tiap-tiap unsur kebudayaan universal sudah tentu juga menjelma dalam ketiga wujud kebudayaan, yaitu wujudnya yang berupa sistem budaya, yang berupa sistem sosial, dan yang berupa unsur-unsur kebudayaan fisik. Hal lain juga diungkapkan oleh Umar Kayam (1981: 3839), bahwa kesenian tidak pernah berdiri lepas dari masyarakat sebagai salah satu bagian yang terpenting dari kebudayaan. Kesenian adalah ungkapan kreativitas dari kebudayaan itu sendiri.

Aneka ragam kebudayaan dan kesenian tradisional yang sudah ada pada zaman dahulu di Indonesia menunjukkan bahwa Indonesia merupakan Negara yang kaya akan kebudayaan dan kesenian tradisional. Aneka ragam kebudayaan dan kesenian tradisional di Indonesia sudah seharusnya dijaga dan dilestarikan agar generasi penerus secara turun temurun tidak kehilangan identitasnya sebagai penduduk Indonesia. Keanekaragaman kebudayaan dan kesenian tradisional di Indonesia sangat perlu dijaga dan dilestarikan karena melihat realita yang ada pada saat ini bahwa banyaknya budaya-budaya dan kesenian asing khususnya seni musik barat yang mulai berdatangan sehingga mempunyai pengaruh sangat besar bagi penduduk Indonesia. Hal tersebut menimbulkan banyaknya kebudayaan dan kesenian tradisional asli Indonesia yang hilang dan punah tergerus oleh modernisasi zaman. Selain itu, hal yang paling krusial yang terjadi pada era sekarang adalah ketika kebudayaan dan kesenian di Indonesia yang dibenturkan dengan aturan-aturan, isu-isu, dan permasalahan agama. Oleh sebab itu, sangat perlu ditanamkan pengetahuan dan wawasan yang luas dan cukup baik pada masyarakat Indonesia akan kebudayaan dan kesenian tradisional Indonesia yang tidak seharusnya dibenturkan dengan permasalahan agama.

Ngawen merupakan salah satu daerah di Propinsi Gunungkidul yang mempunyai kebudayaan dan kesenian tradisional yang beraneka ragam. Musik tradisional Rinding Gumbeng merupakan salah satu simbol kesenian tradisional asli daerah ini. Akan tetapi seiring dengan modernisasi zaman, kesenian musik tradisional Rinding Gumbeng ini perlahan mulai dipertanyakan eksistensinya. Hal tersebut dapat dilihat dari realita yang ada pada saat ini bahwa banyaknya masyarakat Ngawen terutama masyarakat di Gunungkidul yang lebih tertarik untuk menikmati ataupun mempelajari seni musik barat seperti musik popular dan musikmusik modern. Perubahan-perubahan selera musik masyarakat tersebut dapat terjadi oleh adanya perubahan lingkungan masyarakat Gunungkidul, banyaknya elemen kebudayaan material yang masuk dalam lingkungan masyarakat Gunungkidul, dan cara hidup serta pandangan hidup masyarakat Gunungkidul yang berubah.

Berdatangnya musik-musik barat ini tanpa disadari menimbulkan banyak permasalahan dan pengaruh yang sangat besar bagi masyarakat khususnya masyarakat Gunungkidul. Masyarakat sendiri tidak menyadari bahwa seolah-olah dirinya telah diajak untuk mengkonsumsi seni musik barat tersebut yang mengakibatkan rasa "kecanduan". Masyarakat juga diajak untuk mempunyai persepsi bahwa musik tradisional merupakan musik kuno yang tidak penting untuk dipelajari dan kurang bisa dinikmati karena musik seni barat dianggap lebih merepresentasikan perasaan atau sebagai penyalur emosi seseorang. Fenomena tersebut merupakan salah satu bentuk penjajahan bangsa barat yang terlihat sangat nyata pada aktivitas sehari-hari. Akan tetapi, pada sisi lain masyarakat khususnya masyarakat Gunungkidul tidak sadar bahwa dirinya sedang "dijajah" melalui budaya-budaya yang berasal dari barat tersebut.

\section{PEMBAHASAN}

Rinding berasal dari Bahasa Jawa. Alat musik ini disebut rinding karena apabila dibunyikan kedengaran terasa mrinding (meremang bulu kuduknya). Makna dari alat musik rinding ini merupakan kesenian asli 
rakyat yang hidupnya pun berada di tempat yang terpencil (pelosok) (Moertjipto, 1990: 62). Gumbeng merupakan alat musik tradisional yang berasal dari Daerah Karangmojo Gunungkidul. Alat musik ini disebut gumbeng karena bentuknya yang menyerupai sebuah tabung atau pohon bambu itu sendiri. Makna dari alat musik gumbeng adalah seni asli dari rakyat kecil yang hidup di daerah terpencil (Moertjipto, 1990: 79). Pada zaman dahulu, aktivitas musik tradisional rinding gumbeng ini merupakan iringan dalam upacara ritual adat panen padi.

Pada awalnya, setiap pelaksanaan upacara ritual panen padi, para petani hanya menggunakan satu alat musik saja, yaitu rinding. Seiring berjalannya waktu sekitar tahun 80-an, rinding perlahan mulai digabungkan dengan gumbeng yang berasal dari daerah Karangmojo Gunungkidul, sehingga terciptalah kesenian musik tradisional rinding gumbeng. Para seniman rinding gumbeng berusaha membuat alat musik pengiring yang menyerupai seperangkat alat musik gamelan dan juga angklung. Alat musik dari bambu yang telah dibuat sebagai pelangkap musik tradisional rinding gumbeng yaitu gong, kendang, dan kecrek.

Seiring dengan pesatnya perkembangan zaman yang ada, musik tradisional Rinding Gumbeng perlahan mulai ditinggalkan oleh masyarakat terutama masyarakat Gunungkidul. Hal tersebut dapat dilihat dari semakin berkurangnya minat masyarakat yang mempelajari musik tradisional ini. Fenomena ini ditandai dengan minimnya masyarakat yang ikut serta belajar di sanggar-sanggar musik tradisional Rinding Gumbeng, banyaknya sekolah-sekolah di Gunungkidul yang berangsur-angsur harus menutup ekstrakurikuler musik tradisional Rinding Gumbeng karena minimnya siswa yang mengikuti kegiatan ekstrakurikuler tersebut, dan semakin minimnya guru seni Gunungkidul yang menerapkan musik tradisional Rinding Gumbeng ke dalam mata pelajaran seni budaya.

Kondisi-kondisi tersebut disebabkan oleh adanya beberapa faktor yaitu perubahan gaya hidup dan perubahan sosial seperti selera musik masyarakat yang berubah. Selain itu, perubahan selera musik masyarakat juga disebabkan oleh adanya perubahan lingkungan yang ada pada masyarakat sekitar. Perubahan lingkungan akan sangat berdampak pada perubahan sosial masyarakat. Berdasarkan perubahan sosial tersebut, akan mengakibatkan perubahan kebudayaan yang terjadi pada masyarakat. Hal tersebut sesuai dengan pendapat elly (2006: 4445), adanya lima faktor yang menjadi penyebab perubahan kebudayaan, yaitu: (1) Perubahan lingkungan, (2) Perubahan yang disebabkan adanya kontak dengan suatu kelompok lain, (3) Perubahan karena adanya penemuan (discovery), (4) Perubahan yang terjadi karena suatu masyarakat atau bangsa mengadopsi beberapa elemen kebudayaan material yang telah dikembangkan oleh bangsa lain di tempat, (5) Perubahan yang terjadi karena suatu bangsa memodifikasi cara hidupnya dengan mengadopsi suatu pengetahuan atau kepercayaan baru, atau karena perubahan dalam pandangan hidup dan konsepsinya tentang realitas.

Perubahan kebudayaan juga dialami oleh masyarakat Gunungkidul. Hal tersebut dapat dilihat dari aktivitas kesenian musik tradisional rinding gumbeng yang ada di daerah ini. Selera masyarakat yang pada awalnya lebih menyukai musik tradisional asli Gunungkidul ini berangsur-angsur berubah dan lebih tertarik serta menyukai musik-musik popular atau musik seni barat. Hal tersebut disebabkan karena tuntutan dari modernisasi zaman. Perubahanperubahan tersebut dapat terjadi oleh adanya perubahan lingkungan masyarakat Gunungkidul, banyaknya elemen kebudayaan material yang masuk dalam lingkungan masyarakat Gunungkidul, dan cara hidup serta pandangan hidup masyarakat Gunungkidul yang berubah.

Dewasa ini, masyarakat dihadapkan dengan berbagai pilihan yang sulit karena maraknya produk-produk industri kebudayaan yang disajikan. Seperti contohnya, pada saat ini media massa banyak menyajikan berbagai alternatif pilihan musik yang akan dikonsumsi oleh masyarakat. Berbagai pilihan musik yang disajikan lebih mengarah pada musik-musik popular dan seni musik barat seperti musik dangdut, musik reggae, musik jazz, musik hiphop dan lain sebagainya. Musik-musik popular dan musik seni barat cenderung lebih banyak ditampilkan dan diekspos secara besar-besaran dibandingkan musik-musik tradisional yang ada di Nusantara. Akibatnya, masyarakat cenderung lebih menyukai musik-musik popular dan seni musik barat dibandingkan dengan musik tradisional yang lahir dan berkembang di Nusantara. 
Musik-musik popular dan seni musik barat yang disajikan media massa merupakan salah satu bentuk kebudayaan. Williams (dalam Barker, 2015: 40), yang memandang bahwa konsep kebudayaan didasarkan atas konsep 'antropologis' karena terpusat pada makna sehari-hari: nilai (gagasan abstrak), norma (prinsip atau aturan terbatas) dan benda-benda material atau simbolis. Musik-musik popular dan seni musik barat yang dikemas oleh media massa, tidak lepas dari makna yang ada pada kehidupan sehari-hari manusia yaitu berupa nilai, norma, dan benda-benda material atau simbolis. Sarana produksi yang dikemas pada musik-musik seni barat yang ada pada media massa tidak lepas dari sesuatu yang bersifat material. Seperti yang diungkapkan oleh Williams bahwa 'apa pun tujuan praktik kultural, sarana produksinya tak terbantahkan lagi selalu bersifat material (dalam Barker, 2015: 43).

Dewasa ini, tidak terbantahkan lagi banyak masyarakat yang lebih menyukai musikmusik popular dan seni musik barat yang disajikan oleh media massa daripada musikmusik tradisional yang ada di lingkungan sekitar. Masyarakat seakan-akan dibuat 'kecanduan' terhadap seni musik barat yang ditayangkan. Masyarakat sering tidak menyadari bahwa mereka sedang berada pada tahap 'kecanduan'. 'Kecanduan' tersebut disebabkan karena masyarakat belum dapat berpikir secara kritis dalam menemukan letak keindahan, kebaikan, dan nilai yang ada pada tayangan musik tersebut. Seperti yang diungkapkan oleh Leavis dan Arnold bahwa garis demarkasi antara yang baik dengan yang buruk, tinggi dan rendah, terpusat pada pertanyaan tentang kualitas estetis: penilaian atas keindahan, kebaikan dan nilai. Konsep keindahan, bentuk, dan kualitas secara kultural bersifat relatif (dalam Barker, 2015: 43). Pernyataan Leavis dan Arnold tersebut dapat dipahami bahwa penilaian dan pendapat dari seorang manusia yang satu dengan manusia yang lainnya terhadap praktik kultural yaitu musik-musik popular ataupun seni musik barat yang ditayangkan akan sangat berbeda-beda. Hal tersebut tergantung dari ilmu yang dimiliki oleh seseorang, lingkungan, dan lain sebagainya.

Seni adalah industri dengan pemilik, manajer, dan pekerjanya sendiri yang beroperasi menurut hukum keuntungan sebagaimana yang terjadi pada kebudayaan pop dan televisi pop
(Barker, 2015: 45). Teori yang diungkapkan sesuai dengan realita yang terjadi pada saat ini, bahwa seni dipahami sebagai suatu industri kebudayaan. Karya seni bukan dipahami sebagai suatu karya yang kaya akan keindahan atau estetik, akan tetapi seni pada saat ini bertujuan untuk diperjualbelikan. Dewasa ini, seni lebih dekat dengan praktik-praktik industrial. Seperti musik-musik pop ataupun seni musik barat yang disajikan pada media massa sudah barang tentu merupakan konsep industrial yang di dalamnya terdapat pemilik, manajer, dan anggota dari tim produksi yang menjalankan suatu manajeman proyek musik tersebut. Aktor-aktor dibalik layar yang ada dalam manajemen musik tersebut menjadikan proyek musik itu sendiri sebagai sebuah komoditi ekonomi yang menitikberatkan pada kepentingan materialis.

Pandangan Adorno dan Horkheimer (dalam Barker, 2015: 47), yang memadukan frase 'Industri Kebudayaan' untuk menunjukkan bahwa kebudayaan kini sepenuhnya saling berpautan dengan ekonomi politik dan produksi kebudayaan oleh perusahaan-perusahaan kapitalis. Perusahaan-perusahaan kapitalis bekerja dengan berorientasi pada uang dan banyaknya sasaran konsumen, tanpa mereka berpikir dampak dan efek jangka panjang yang akan ditimbulkan oleh masyarakat pada masa yang akan datang. Dengan kata lain, pemilik perusahaan-perusahaan kapitalis bekerja menurut hukum keuntungan dan kekuasaaan dari jabatan-jabatan yang dimiliki. Seperti pemilik-pemilik dari perusahaan kapitalis yang membuat suatu proyek musik yang diekspos pada media massa, mempunyai kekuasaan yang lebih luas untuk mengatur anggota-anggota dari tim produksi yang menjalankan proyek musik tersebut. Sehingga tidak jarang, di balik layar penyajian musik-musik pop ataupun seni musik barat yang terkesan menyenangkan dan meriah tersebut, terdapat banyak kepentingan dan ide dari kelas-kelas yang berkuasa yaitu pemilik perusahaan-perusahaan kapitalis.

Musik-musik pop dan seni musik barat yang disajikan pada media massa merupakan sebuah produk industri kebudayaan yang sudah disediakan sedemikian rupa oleh perusahaan kapitalis sehingga membuat masyarakat menjadi 'kecanduan' dan tidak bisa lepas dari musikmusik tersebut. Dengan kata lain, masyarakat cenderung akan terus mengikuti trend musik yang disajikan, dan apabila masyarakat tidak 
menonton atau mendengarkan musik-musik tersebut dalam sehari saja akan timbul perasaan sedih dan mengganjal atau tidak nyaman. Hal tersebut sesuai dengan yang diungkapkan Barker (2015: 47), bahwa keseragaman produk industri kebudayaan adalah ilusi untuk sesuatu yang disediakan bagi semua orang sehingga tak seorangpun bisa lari darinya. Makna dari musikmusik pop atau seni musik barat yang disajikan cenderung ditelan mentah-mentah oleh masyarakat, tanpa masyarakat berusaha untuk berpikir kritis ataupun menilai segala aspek dari musik-musik tersebut. Seperti yang diungkapkan analisis Mahzab Frankfurt (dalam Barker, 2015: 48), bahwa makna yang telah teridentikkan ditelan mentah-mentah oleh audiens.

De Certeau (dalam Barker, 2015: 49), berpendapat bahwa konsumsi bersifat menipu, tercerai-berai, namun ada dimana-mana, secara sembunyi-sembunyi dan hampir tak terlihat, karena ia tidak mewujudkan dirinya melalui produknya sendiri, melainkan melalui cara pemanfaatan produk yang dipaksakan oleh tatanan ekonomi dominan. Pendapat Certeau sesuai dengan realita yang ada, bahwa banyaknya masyarakat Indonesia yang pada saat ini mengonsumsi berbagai produk industri kebudayaan, seperti contohnya musik-musik pop atau seni musik barat yang disajikan oleh media massa. Musik-musik yang disajikan bersifat menipu masyarakat, hadir atau terdapat dimana saja, dan hampir tidak terlihat. Hal tersebut dikarenakan produk musik-musik popular dan musik seni barat tersebut tidak mewujudkan dirinya melalui produknya sendiri, akan tetapi dapat dilihat melalui cara pemanfaatan produk musik tersebut yang terlihat dipaksakan oleh sebuah tatanan ekonomi yang sedang dominan di lingkup masyarakat.

Pada kenyataannya, saat ini industri kebudayaan sering memaksa masyarakat untuk selalu mengkonsumsi kebudayaan massa. Hal tersebut dapat dilihat pada musik-musik dan seni musik barat yang disajikan oleh media massa. Kondisi masyarakat pada saat ini seakan-akan dipaksa oleh para pemilik industri kebudayaan untuk mengkonsumsi musik-musik pop atau seni musik barat yang disajikan. Para pemilik industri kebudayaan bekerja keras dan saling berkompetisi agar produknya lebih unggul dari yang lain dan laku terjual di masyarakat. Seperti pendapat Fiske bahwa industri kebudayaan harus bekerja keras untuk memaksa kita mengonsumsi kebudayaan massa (dalam Barker, 2015: 49).

Musik-musik pop atau seni musik barat yang ditayangkan oleh media massa dipahami sebagai sebuah bentuk kebudayaan massa. 'Kebudayaan massa' kapitalis yang terkomodifikasi tidak autentik karena tidak dihasilkan oleh 'masyarakat', manipulatif karena tujuan utamanya adalah agar dibeli, dan tidak memuaskan karena, selain mudah dikonsumsi, ia pun tidak mensyaratkan terlalu banyak kerja dan gagal memperkaya batin konsumennya (Barker, 2015:47). Seperti contohnya musik pop atau seni musik barat yang ditayangkan di televisi maupun media massa merupakan hasil dari kepentingan kaum kapitalis yang sudah terkomodifikasi. Musik tersebut dipahami sebagai sesuatu yang tidak autentik karena tidak dihasilkan oleh masyarakat itu sendiri, akan tetapi dihasilkan oleh kepentingan-kepentingan dan ide-ide dari berbagai pemilik perusahaan kapitalis. Musik pop dan seni musik barat yang disajikan pada masyarakat juga bersifat manipulatif, dapat dimaknai bahwa tujuan utamanya adalah dibeli dan dinikmati oleh konsumen yaitu masyarakat dan target utamanya adalah sasaran pasar. Musik yang disajikan dengan mudahnya dikonsumsi oleh masyarakat, sehingga terkadang masyarakat menelan mentah-mentah pada sajian karya musik pop atau seni musik barat yang dibawakan oleh penyanyi-penyanyi tanpa memahami nilai ataupun makna yang terkandung pada karya musik tersebut. Dengan kata lain, musik pop dan seni musik musik barat yang disajikan pada saat ini, gagal untuk memperkaya batin masyarakat.

Kebudayaan pop merupakan kebudayaan yang diproduksi secara komersial dan tidak ada alasan untuk berpikir bahwa tampaknya ia akan berubah di masa yang akan datang (Barker, 2015: 50). Hal tersebut sesuai dengan pola konsumsi masyarakat terhadap musik pop dan seni musik barat yang disajikan oleh media massa. Musik-musik tersebut diproduksi oleh para pemilik industri kebudayaan secara komersial. Pola konsumsi masyarakat juga tidak akan berubah pada masa yang akan datang, walaupun alternatif pilihan musik yang ditayangkan dapat berubah sewaktu-waktu. Pada sisi lain, kebudayaan pop dipandang sebagai makna dan praktik yang dihasilkan oleh audiens pop pada saat konsumsi dan studi tentang kebudayaan pop terpusat pada bagaimana dia digunakan (Barker, 2015: 50). Hal tersebut 
dapat dipahami bahwa kebudayaan pop tidak lepas dari makna dan praktik yang dihasilkan dari masyarakat sebagai konsumen pada musik pop dan seni musik barat yang ditayangkan atau disajikan oleh media massa.

Pengaruh musik dalam kehidupan manusia khususnya musik tradisional yang ada di Nusantara mulai dikesampingkan. Musik pop atau seni musik barat pada saat ini mulai menjadi dewa-dewi di tengah masyarakat. Masyarakat beranggapan bahwa musik pop ataupun musik seni barat merupakan musik yang dapat memberikan pengaruh yang besar terhadap kehidupan manusia. Musik pop ataupun musik seni barat dianggap sebagai representasi perasaan dan sebagai penyalur emosi seseorang. Musik seni barat lebih bisa untuk dinikmati oleh masyarakat daripada musik-musik tradisional yang ada di Nusantara. Advokasi mengenai efek musik dengan penjelasan teknis yang sedemikian rupa juga seolah berusaha meyakinkan bahwa musik tertentu memiliki keampuhan yang luarbiasa (Salim. 2007:42). Akibatnya, musik tradisional yang ada di Nusantara seperti musik tradisional Rinding Gumbeng perlahan mulai ditinggalkan dan diabaikan oleh masyarakat.

Gejolak-gejolak yang timbul pada masyarakat Gunungkidul tersebut merupakan efek dari post-kolonial. Masyarakat tidak menyadari bahwa dirinya sedang dijajah oleh bangsa barat melalui berbagai cara seperti datangnya atau masuknya kesenian musik barat di Indonesia. Timur merupakan bagian tak terpisahkan dari peradaban dan kebudayaan material Eropa (Said, 2016: 2). Bangsa timur dijadikan alat materialisasi oleh bangsa barat melalui kebudayaannya. Oleh sebab itu, bangsa barat selalu memperoleh kekuatan dan kekuasaan dari bangsa timur. Bangsa barat seakan-akan menjadi dewa pelindung masyarakat dari bangsa timur. Kebudayaan Eropa memperoleh kekuatan dan identitasnya dengan cara mempertentangkan dirinya terhadap dunia Timur sebagai semacam wali atau pelindung, bahkan "diri" yang tersembunyi (Said, 2016: 4).

Indonesia merupakan salah satu Negara yang pada zaman dahulu pernah terjajah secara fisik. Pasca-kolonial merupakan seperangkat pernyataan mengenai kondisi dan kecenderungan masyarakat yang terjajah dan pernah terjajah (Faruk. 2007: 16). Dewasa ini, kondisi dari Negara Indonesia juga masih terjajah, akan tetapi bentuk penjajahan tersebut bukan secara fisik melainkan secara ideologi. Bentuk penjajahan secara ideologi melalui moral, kebudayaan, pengetahuan, politik, militer, ekonomi, dan lain sebagainya. Kebudayaan Eropa mampu menangani dan menciptakan dunia Timur secara politis, sosiologis, militer, ideologis, ilmiah, dan imajinatif selama masa pasca-Penceraham (Said, 2016: 4). Bentuk penjajahan dapat terlihat dengan jelas, akan tetapi masyarakat Indonesia tidak menyadari bahwa dirinya sedang terjajah. Hal tersebut disebabkan karena pola pikir dan pengetahuan masyarakat Indonesia yang cenderung kurang bersikap kritis terhadap apa yang dialami pada kehidupan sehari-hari. Segala kenikmatan palsu yang disajikan bangsa barat seolah-olah diterima, ditelan mentah-mentah, dan tidak disadari oleh masyarakat.

Masyarakat Indonesia dihadapkan pada kekaburan terhadap apa yang dimiliki oleh bangsanya. Berbagai kekayaan kebudayaan dan kesenian yang dimiliki merupakan harta yang paling berharga bagi Bangsa Indonesia. Akan tetapi, saat ini bangsa Indonesia seolah menjadi kaum terjajah. Para penjajah memulai praktik kekuasaannya dengan mengatur dan mengendalikan masyarakat melalui pikiran, perasaan, sikap, bahkan jiwa raganya. Masyarakat yang pikiran, perasaan, sikap, perilaku, dan bahkan tubuhnya diduduki, dikuasai, diatur, dan dikendalikan oleh penjajah melalui praktik, teori, dan sikap yang ditanamkan padanya (Faruk. 2007: 16).

Bentuk penjajahan oleh bangsa barat tersebut secara terang-terangan terlihat pada media massa yang marak pada saat ini. Konsep dari Gramsci, pengelola media massa sebenarnya tengah menghegemoni audiens (Tim Penulis. 2013: xii). Dengan kata lain, bahwa sesungguhnya masyarakat sedang dibuat tunduk oleh media massa tanpa mereka menyadari bahwa diri mereka sedang dieksploitasi. Pada kerangka ini dapat dipahami bahwa media massa tengah melakukan kolonisasi atau penjajahan terhadap masyarakat. Akan tetapi, ironisnya masyarakat tidak menyadari bahwa dirinya sedang ada dieksploitasi, didominasi ataupun dijajah oleh media massa. Hal tersebut dipahami sebagai kekerasan simbolik yang dilakukan oleh media massa. Industri media sering berlaku mekanisme kekerasan simbolik, 
yakni kekerasan yang berbasis pada persetujuan korbannya (Haryatmoko, 2007: 12). Kekerasan tersebut berbentuk dominasi dan si korban itu sering tidak menyadari bahwa dirinya sebenarnya tengah menjadi korban kekerasan (Tim Penulis. 2013: xii).

\section{PENUTUP}

Musik tradisional Rinding Gumbeng merupakan salah satu simbol kesenian tradisional asli daerah Ngawen Gunungkidul. Akan tetapi seiring dengan perkembangan modernisasi zaman, musik tradisional Rinding Gumbeng ini perlahan mulai dipertanyakan eksistensinya. Hal tersebut dapat dilihat dari realita yang ada pada saat ini bahwa banyaknya masyarakat Ngawen terutama masyarakat di Gunungkidul yang lebih tertarik untuk menikmati ataupun mempelajari seni musik barat seperti musik popular dan musik-musik modern. Perubahan-perubahan selera musik masyarakat tersebut dapat terjadi oleh adanya perubahan lingkungan masyarakat Gunungkidul, banyaknya elemen kebudayaan material yang masuk dalam lingkungan masyarakat Gunungkidul, dan cara hidup serta pandangan hidup masyarakat Gunungkidul yang berubah.

Dewasa ini, masyarakat dihadapkan dengan berbagai pilihan yang sulit karena maraknya produk-produk industri kebudayaan yang disajikan. Seperti contohnya, pada saat ini media massa banyak menyajikan berbagai alternatif pilihan musik yang akan dikonsumsi oleh masyarakat. Berbagai pilihan musik yang disajikan lebih mengarah pada musik-musik popular dan seni musik barat seperti musik dangdut, musik reggae, musik jazz, musik hiphop, dan lain sebagainya. Musik-musik popular dan musik seni barat cenderung lebih banyak ditampilkan dan diekspos secara besar-besaran dibandingkan musik-musik tradisional yang ada di Nusantara. Akibatnya, masyarakat cenderung lebih menyukai musik-musik popular dan seni musik barat dibandingkan dengan musik tradisional yang lahir dan berkembang di Nusantara.

Musik-musik pop dan seni musik barat yang disajikan pada media massa merupakan sebuah produk industri kebudayaan yang sudah disediakan sedemikian rupa oleh perusahaan kapitalis sehingga membuat masyarakat menjadi 'kecanduan' dan tidak bisa lepas dari musikmusik tersebut. Perusahaan-perusahaan kapitalis bekerja dengan berorientasi pada uang dan banyaknya sasaran konsumen, tanpa mereka berpikir dampak dan efek jangka panjang yang akan ditimbulkan oleh masyarakat pada masa yang akan datang. Dengan kata lain, pemilik perusahaan-perusahaan kapitalis bekerja menurut hukum keuntungan dan kekuasaaan dari jabatan-jabatan yang dimiliki.

Musik pop atau seni musik barat yang ditayangkan di televisi maupun media massa merupakan hasil dari kepentingan kaum kapitalis yang sudah terkomodifikasi. Musik tersebut dipahami sebagai sesuatu yang tidak autentik karena tidak dihasilkan oleh masyarakat itu sendiri, akan tetapi dihasilkan oleh kepentingan-kepentingan dan ide-ide dari berbagai pemilik perusahaan kapitalis. Musik pop dan seni musik barat yang disajikan pada masyarakat juga bersifat manipulatif, dapat dimaknai bahwa tujuan utamanya adalah dibeli dan dinikmati oleh konsumen yaitu masyarakat dan target utamanya adalah sasaran pasar. Musik yang disajikan dengan mudahnya dikonsumsi oleh masyarakat, sehingga terkadang masyarakat menelan mentah-mentah pada sajian karya musik pop atau seni musik barat yang dibawakan oleh penyanyi-penyanyi tanpa memahami nilai ataupun makna yang terkandung pada karya musik tersebut. Dengan kata lain, musik pop dan seni musik musik barat yang disajikan pada saat ini, gagal untuk memperkaya batin masyarakat.

Gejolak dan perubahan selera musik yang timbul pada masyarakat Gunungkidul tersebut merupakan efek dari post-kolonial. Pada saat ini Indonesia tetap masih terjajah, akan tetapi bentuk penjajahan tersebut bukan secara fisik melainkan secara ideologi. Bentuk penjajahan secara ideologi melalui moral, kebudayaan, pengetahuan, politik, militer, ekonomi, dan lain sebagainya. Masyarakat tidak menyadari bahwa dirinya sedang dijajah oleh bangsa barat melalui berbagai cara seperti datangnya atau masuknya seni musik barat di Indonesia. Bentuk penjajahan dapat terlihat dengan jelas dan secara terang-terangan seperti yang ada pada media massa, akan tetapi masyarakat Indonesia tidak menyadari bahwa dirinya sedang terjajah. Hal tersebut disebabkan karena pola pikir dan pengetahuan masyarakat Indonesia yang cenderung kurang bersikap kritis terhadap apa yang dialami pada kehidupan sehari-hari. Segala kenikmatan palsu yang disajikan bangsa barat seolah-olah diterima, ditelan mentah-mentah, dan tidak disadari oleh masyarakat. Bangsa timur dijadikan alat materialisasi oleh bangsa 
barat melalui kebudayaannya. Oleh sebab itu, bangsa barat selalu memperoleh kekuatan dan kekuasaan dari bangsa timur. Bangsa barat seakan-akan menjadi dewa pelindung masyarakat dari bangsa timur.

\section{DAFTAR PUSTAKA}

Barker, Chris. Cultural Studies. Cetakan kesembilan. Yogyakarta: Kreasi Wacana. 2015.

Elly, dkk. Ilmu sosial dan budaya dasar. Indonesia: Kencana Prenadamedia Group. 2006.

Faruk. Belenggu Pasca-Kolonial. Yogyakarta: Pustaka Pelajar. 2007.

Haryatmoko. Etika Komunikasi. Yogyakarta: Kanisius. 2007.

Kayam, Umar. Seni Tradisi Masyarakat. Jakarta: Sinar Harapan. 1981.

Koentjaraningrat. Pengantar Ilmu Antropologi. Jakarta: Rhineka Cipta. 2000.

Moertjipto, dkk. Bentuk-bentuk Peralatan Hiburan dan Kesenian Tradisional. Jakarta: Depdikbud. 1990.

Said, Edward. Orientalisme: Menggugat Hegemoni Barat dan Mendudukkan Timur sebagai Subjek. Cetakan kedua. Yogyakarta: Pustaka Pelajar. 2016.

Tim Penulis. Kolonialisasi Media Televisi. Yogyakarta: Buku Litera. 2013. 